\title{
Bovine herpesvirus 4 is tropic for bovine endometrial cells and modulates endocrine function
}

\author{
Gaetano Donofrio, Shan Herath ${ }^{1}$, Chiara Sartori, Sandro Cavirani, Cesidio Filippo Flammini and \\ lain Martin Sheldon ${ }^{1}$ \\ Dipartimento di Salute Animale, Sezione di Malattie Infettive, Facoltà di Medicina Veterinaria, via del Taglio 8, 43100 \\ Parma, Italy and ${ }^{1}$ Department of Veterinary Clinical Sciences, Royal Veterinary College, University of London, Royal \\ College Street, London NW1 OTU, UK \\ Correspondence should be addressed to G Donofrio; Email: gaetano.donofrio@unipr.it
}

\begin{abstract}
Bovine postpartum uterine disease, metritis, affects about $40 \%$ of animals and is widely considered to have a bacterial aetiology. Although the $\gamma$-herpesvirus bovine herpesvirus 4 (BoHV-4) has been isolated from several outbreaks of metritis or abortion, the role of viruses in endometrial pathology and the mechanisms of viral infection of uterine cells are often ignored. The objectives of the present study were to explore the interaction, tropism and outcomes of BoHV-4 challenge of endometrial stromal and epithelial cells. Endometrial stromal and epithelial cells were purified and infected with a recombinant BoHV-4 carrying an enhanced green fluorescent protein (EGFP) expression cassette to monitor the establishment of infection. BoHV-4 efficiently infected both stromal and epithelial cells, causing a strong non-apoptotic cytopathic effect, associated with robust viral replication. The crucial step for the BoHV-4 endometriotropism appeared to be after viral entry as there was enhanced transactivation of the BoHV-4 immediate early 2 gene promoter following transient transfection into the endometrial cells. Infection with BoHV-4 increased cyclooxygenase 2 protein expression and prostaglandin estradiol secretion in endometrial stromal cells, but not epithelial cells. Bovine macrophages are persistently infected with BoHV-4, and co-culture with endometrial stromal cells reactivated BoHV-4 replication in the persistently infected macrophages, suggesting a symbiotic relationship between the cells and virus. In conclusion, the present study provides evidence of cellular and molecular mechanisms, supporting the concept that BoHV-4 is a pathogen associated with uterine disease. Reproduction (2007) 134 183-197
\end{abstract}

\section{Introduction}

Bovine herpesvirus 4 (BoHV-4) was originally included in the $\beta$-herpesvirinae subfamily and referred to as bovine cytomegalovirus, primarily because its biological properties in tissue culture most closely resembled those of human cytomegaloviruses (Storz et al. 1984). However, molecular evidence has accumulated which indicate that BoHV-4 is genetically more closely related to members of the $\gamma$-herpesvirinae subfamily. This evidence includes large blocks of homologous genes arranged in the same order as two other $\gamma$-herpesviruses, Epstein-Barr virus and herpesvirus saimiri (Bublot et al. 1992). BoHV-4 replicates in a broad range of cell lines and primary cultures, causing a cytopathic effect (CPE; Truman et al. 1986, Peterson \& Goyal 1988, Donofrio et al. 2002, Gillet et al. 2004). However, like other herpesviruses, BoHV-4 can establish persistent infections in its natural host (Krogman \& McAdaragh 1982, Osorio \& Reed 1983, Dubuisson et al. 1989, Dewals et al. 2005) and experimental hosts such as the rabbit (Osorio et al. 1982). Although the presence of BoHV-4 has been demonstrated in many tissues, the cells of the monocyte/macrophage lineage are a common site of persistence in natural and experimental hosts (Osorio \& Reed 1983, Osorio et al. 1985a, 1985b, Dubuisson et al. 1988, 1989, Naeem et al. 1993). Cell lines persistently infected with $\gamma$-herpesviruses such as Epstein-Barr virus, herpesvirus saimiri, human herpesvirus 8 and murine $\gamma$-herpesvirus-68 have been established from cells isolated from infected hosts (Nilsson 1979, Ceserman et al. 1995, Usherwood et al. 1996, Jung et al. 1999). This process has likely been greatly facilitated by the growth-transforming ability of these $\gamma$-herpesviruses (Miller et al. 1997, Flore et al. 1998, Jung et al. 1999, Moses et al. 1999). In contrast, no evidence of growth transformation has been obtained for BoHV-4. Each of the genes associated with transformation by other $\gamma$-herpesviruses is unique to each virus, and a homologous gene is not found in BoHV-4 (Lomonte et al. 1996). 
BoHV-4 was first isolated in Europe from animals with respiratory and ocular diseases by Bartha et al. (1966) and later in the United States by Mohanty et al. (1971). BoHV-4 has been isolated from a variety of samples and cells from healthy cattle and animals with metritis, abortion, pneumonia, diarrhoea, respiratory infection or mammary dermatitis (Bartha et al. 1966, Thiry et al. 1988, Egyed 1998). The pathogenic role of BoHV-4 remains unclear, and correlations between BoHV-4 and disease are unresolved even by experimental infection. Indeed, few investigators have successfully produced experimental disease (Thiry et al. 1988), and direct inoculation of the natural host only occasionally elicited respiratory and genital diseases including abortion (Wellemans et al. 1986, Castrucci et al. 1987).

Abortion may follow infection with a variety of $\alpha-, \beta$ and $\gamma$-herpesvirus, but viral causes of uterine disease are seldom investigated in cattle. Although postpartum metritis affects up to $40 \%$ of cattle, causing considerable infertility and economic loss, it has been assumed that most diseases are of bacterial origin and virus isolation or serology is rarely considered (Sheldon \& Dobson 2004). The first reported isolation of BoHV-4 from a case of bovine metritis was in Park \& Kendrick (1973). Later, several other isolates were obtained from cows with reproductive disorders from different countries, including Italy (Castrucci et al. 1986) and India (Mehrotra et al. 1986). In Belgium, BoHV-4 seroprevalence was associated with postpartum metritis and chronic infertility of cattle (Czaplicki \& Thiry 1998). Postpartum metritis has also been associated with BoHV4 in the USA (Frazier et al. 2001, 2002), Spain (Monge et al. 2006) and Serbia (Nikolin et al. 2007). There is a lacuna in the knowledge about the direct correlation between viral infection and uterine pathology. Thus, the objectives of the present study were to determine the interaction, tropism and outcome of BoHV-4 challenge of endometrial epithelial and stromal cells.

\section{Materials and Methods}

\section{Endometrial cell isolation and primary cultures}

To better understand the interaction of BoHV-4 with the endometrium, it was important to use purified populations of epithelial and stromal cells without contamination by leukocytes, because BoHV-4 function can be influenced by macrophages (Donofrio \& van Santen 2001). Bovine uteri from post-pubertal non-pregnant BoHV-4 serum-negative animals with no evidence of genital disease were collected at a local abattoir immediately after slaughter and kept on ice until further processing in the laboratory. The physiological stage of the reproductive cycle for each genital tract was determined by observation of the ovarian morphology (Ireland et al. 1980). Genital tracts with an ovarian stage I corpus luteum were selected for endometrial tissue and cell culture, and only the horn ipsilateral to the corpus luteum was used.

The endometrium was cut into strips and placed into serum-free RPMI-1640 (Sigma) supplemented with $50 \mathrm{IU} / \mathrm{ml}$ penicillin, $50 \mu \mathrm{g} / \mathrm{ml}$ streptomycin and $2.5 \mu \mathrm{g} / \mathrm{ml}$ amphotericin B (Sigma), working under sterile conditions. The strips were then chopped into $1 \mathrm{~mm}^{3}$ pieces and placed into Hanks Balanced Salt Solution (HBSS; Sigma) and used as previously described (Fortier et al. 1988, Asselin et al. 1996), with the following modifications. Briefly, tissue was digested in $25 \mathrm{ml}$ sterile filtered digestive solution, which was made by dissolving $50 \mathrm{mg}$ trypsin III (Roche), $50 \mathrm{mg}$ collagenase II (Sigma), $100 \mathrm{mg}$ BSA (Sigma) and $10 \mathrm{mg}$ DNase I (Sigma) in $100 \mathrm{ml}$ phenol red-free HBSS. Following a $1.5 \mathrm{~h}$ incubation in a shaking water bath at $37^{\circ} \mathrm{C}$, the cell suspension was filtered through a $40 \mu \mathrm{m}$ mesh (Fisher Scientific) to remove undigested material and the filtrate was resuspended in phenol red-free HBSS containing $10 \%$ fetal bovine serum (FBS; Sigma) and $3 \mu \mathrm{g} / \mathrm{ml}$ trypsin inhibitor (Sigma; washing medium). The suspension was centrifuged at $100 \boldsymbol{g}$ for $10 \mathrm{~min}$ and following two further washes in washing medium the cells were resuspended in RPMI-1640 containing 10\% FBS, $50 \mathrm{IU} / \mathrm{ml}$ penicillin, $50 \mu \mathrm{g} / \mathrm{ml}$ streptomycin and $2.5 \mu \mathrm{g} / \mathrm{ml}$ amphotericin B. The cells were plated at a density of $1 \times 10^{5}$ cells in $2 \mathrm{ml}$ per well using 24-well plates (Nunc). To obtain separate stromal and epithelial cell populations, the cell suspension was removed $18 \mathrm{~h}$ after plating, which allowed selective attachment of stromal cells (Fortier et al. 1988). The removed cell suspension was then replated and incubated, allowing epithelial cells to adhere (Kim \& Fortier 1995). Stromal and epithelial cell populations were distinguished by cell morphology as previously described (Fortier et al. 1988). The absence of immune cells in the uterine cell cultures was confirmed by RT-PCR for the CD45 pan-leukocyte marker as previously described (Herath et al. 2006). The culture media was changed every $48 \mathrm{~h}$ until the cells reached confluence. All cultures were maintained at $37^{\circ} \mathrm{C}$ with $5 \% \mathrm{CO}_{2}$ in air, in a humidified incubator.

\section{Cell line cultures}

To explore BoHV-4 tropism, the effect of viral challenge of the endometrial cells was compared with other cells, including Madin-Darby bovine kidney (MDBK, ATCC, CCL-22), and from M Ferrari (Istituto Zooprofilattico, Brescia, Italy) bovine embryo kidney (BEK), bovine embryo lung (BEL) and bovine turbinates (BT). The cells were maintained as monolayers in DMEM (Cambrex), containing $10 \% \mathrm{FBS}, 2 \mathrm{~mm}$ L-glutamine, $100 \mathrm{IU} / \mathrm{ml}$ penicillin and $10 \mu \mathrm{g} / \mathrm{ml}$ streptomycin. The cells were incubated at $37{ }^{\circ} \mathrm{C}$ with $5 \% \mathrm{CO}_{2}$ in air, in a humidified incubator and subcultured when growth reached $70-90 \%$ confluence every $3-5$ days. 


\section{Virus}

To test the susceptibility of cells to BoHV-4 infection, a recombinant BoHV-4 expressing enhanced green fluorescent protein was employed. Recombinant BoHV4EGFP $\Delta$ TK was obtained by insertion of the cytomegalovirus/enhanced green fluorescent protein (CMV/EGFP) expression cassette from the $\mathrm{pEGFP-C1}$ plasmid into the thymidine kinase (TK) locus of the DN 599 BoHV-4 strain (Donofrio et al. 2002). BoHV-4EGFPATK and the NADL strain of bovine viral diarrhoea virus (BVDV) were propagated by infecting confluent monolayers of MDBK at a multiplicity of infection (m.o.i.) of 0.5 tissue cell infectious doses/50 ( TCID $\left._{50}\right)$ per cell and maintained in minimum essential medium (MEM) with $2 \%$ FBS for $2 \mathrm{~h}$. The medium was then removed and replaced by fresh MEM containing $10 \%$ FBS. The virus was purified when $\sim 90 \%$ of the cell monolayer exhibited a CPE, at $\sim 72 \mathrm{~h}$ post-infection (P.I.). Cell-associated virions were freed by three cycles of freezing the flasks at $-80{ }^{\circ} \mathrm{C}$ and thawing. Cell debris was removed by low-speed centrifugation $(1000 \times \mathbf{g})$ and virions were pelleted through a $3 \mathrm{ml}$ cushion of $30 \%$ sucrose in PBS, in a Beckman 70 Ti rotor at 35000 r.p.m. $(100000 \times \mathbf{g})$ for $90 \mathrm{~min}$ at $4{ }^{\circ} \mathrm{C}$. Viral pellets were resuspended in cold MEM without FBS and $\mathrm{TCID}_{50}$ were determined on MDBK cells by limiting dilution (Vanderplasschen et al. 1995).

\section{Infection of primary cell cultures with BoHV-4}

Stromal and epithelial cells were challenged once confluence had been reached with BoHV-4EGFPTK at the concentrations indicated in results, or $1 \mu \mathrm{g} / \mathrm{ml} \mathrm{O55:B5}$ lipopolysaccharide (LPS, Sigma) as a positive control. Viral infection was monitored every $12 \mathrm{~h}$ by observation of cell fluorescence using a fluorescence microscope (Axiovert S100, Zeiss). The supernatants were harvested and frozen at $-20{ }^{\circ} \mathrm{C}$ until used for prostaglandin RIA, and the endometrial cells were collected immediately for RNA isolation and further analysis.

\section{MTT cell survival assay}

CPE is the morphological change associated with the detrimental effects of viral replication on host cell homeostasis that ends with cell death. For epithelial cells, the CPE induced by BoHV-4 is characterised by swelling, whilst stromal cells shrink and detach from the surface of the culture flask. The 3-(4,5-dimethylthiazol2-yl)-2,5-diphenyltetrazolium bromide (MTT) cell metabolic assay was used to measure the number of live cells. Briefly, $48 \mathrm{~h}$ after infection with BoHV-4EGFP $\Delta$ TK, the cell cultures were incubated for $4 \mathrm{~h}$ with $100 \mu \mathrm{g} /$ well MTT before addition of $100 \mu$ l solubilisation solution $(10 \%$ SDS in $\mathrm{HCl} 0.01 \mathrm{M})$ and further incubation for $16 \mathrm{~h}$ at $37^{\circ} \mathrm{C}$. The yellow tetrazolium MTT salt is reduced in metabolically active cells to form insoluble purple formazan crystals, which are solubilised by the addition of a detergent. The optical density was measured at $540 \mathrm{~nm}$, using $690 \mathrm{~nm}$ as the reference wavelength in an SLT-Lab microreader (Salzburg, Austria); for each cell type, a linear relationship between cell number and optical density had already been established. Each experiment was done thrice and each treatment was performed with eight replicates. Statistical differences among treatments were tested by ANOVA.

\section{Apoptosis assays and viral production}

Apoptosis assays were performed because CPE by viruses such as BVDV is mediated by apoptosis. BVDVor BoHV-4EGFPATK-infected confluent monolayers were gently scraped from $25 \mathrm{~cm}^{2}$ flasks with a sterile scraper in the presence of culture medium and the cells were pelleted by centrifugation at $12000 \mathrm{~g}$ for $1 \mathrm{~h}$ at $4{ }^{\circ} \mathrm{C}$. The cell pellet was gently resuspended in $500 \mu \mathrm{l}$ extraction buffer $(400 \mathrm{mM} \mathrm{NaCl}, 10 \mathrm{mM}$ Tris- $\mathrm{HCl}, \mathrm{pH}$ 7.8, $1 \mathrm{mM}$ EDTA and $0.1 \% \mathrm{NP} 40$ ), transferred to a polypropylene microcentrifuge tube and kept on ice for $30 \mathrm{~min}$. The solution was centrifuged at $12000 \mathrm{~g}$ for $15 \mathrm{~min}$, the supernatant recovered carefully in a fresh microfuge tube and extracted with phenol. The aqueous phase was transferred to a microfuge tube and a 0.1 volume of $10 \mathrm{M}$ ammonium acetate and 1 volume of isopropanol added, mixed and centrifuged at $12000 \mathrm{~g}$ for $5 \mathrm{~min}$. The supernatant was removed and the white nucleic acid pellet washed with $500 \mu \mathrm{l}$ of $70 \%$ ethanol and dissolved in $20 \mu \mathrm{l} \mathrm{TE}(10 \mathrm{mM}$ Tris- $\mathrm{HCl}, 0.1 \mathrm{mM}$ EDTA, pH 7.8) containing $20 \mu \mathrm{g} / \mathrm{ml}$ DNase-free pancreatic RNase (Sigma). Nuclear fragments were examined by electrophoresis in a 1.5\% agarose gel and visualised by u.v. after staining with ethidium bromide.

For propidium iodide staining, cells were washed with PBS, stained with $400 \mathrm{ng} / \mathrm{ml}$ propidium iodine for $30 \mathrm{~s}$ in the darkness and fragmented nuclei were visualised by fluorescence microscopy.

Viral production by BT, BEL, MDBK, BEK, endometrial epithelial and stromal cells was tested after infecting cells with 1 m.o.i. of BoHV-4EGFPATK. The viral inoculums were removed after a 3-h absorption period and replaced with fresh media, and the viral titre quantified $48 \mathrm{~h} \mathrm{P.I.}$

\section{Cell culture electroporation and viral reconstitution}

To determine which step of the virus life cycle is important for the expression of the tropic phenotype, a reconstitution viral assay was performed. MDBK, BT and BEK cells from a sub-confluent $25 \mathrm{~cm}^{2}$ flask were electroporated (Equibio apparatus, $270 \mathrm{~V}, 960 \mu \mathrm{F}$ ) with $2 \mu \mathrm{g}$ viral DNA purified as previously described (Gillet et al. 2005) in DMEM without serum and antibiotics. Electroporated cells were returned to new $25 \mathrm{~cm}^{2}$ flasks and fed with DMEM containing 10\% FBS, $2 \mathrm{~mm}$ 
L-glutamine, $100 \mathrm{IU} / \mathrm{ml}$ penicillin and $10 \mu \mathrm{g} / \mathrm{ml}$ streptomycin. Endometrial stromal, endometrial epithelial and BEL cells from a sub-confluent $25 \mathrm{~cm}^{2}$ flask were electroporated (Equibio apparatus, Opty-Puls, $300 \mathrm{~V}$, $25 \mu \mathrm{F}, 240 \mathrm{~V}, 1050 \mu \mathrm{F}$ and $481 \mathrm{R}$ ) with $2 \mu \mathrm{g}$ viral DNA in DMEM with $10 \%$ FBS. Electroporated cells were returned to new $25 \mathrm{~cm}^{2}$ flasks and stromal and epithelia cells were fed with RPMI-1640 containing 10\% FBS, $50 \mathrm{IU} / \mathrm{ml}$ of penicillin, $50 \mathrm{~g} / \mathrm{ml}$ streptomycin and $2.5 \mathrm{~g} / \mathrm{ml}$ amphotericin B and BEL cells with $90 \%$ DMEM containing $10 \%$ FBS, $2 \mathrm{~mm}$ L-glutamine, $100 \mathrm{IU} / \mathrm{ml}$ penicillin and $10 \mu \mathrm{g} / \mathrm{ml}$ streptomycin. The time necessary for the formation of viral plaques was monitored every $24 \mathrm{~h}$ by fluorescence microscopy.

\section{Recombinant IE2 plasmid construction and transfection}

To further investigate the mechanisms associated with endometrial tropism, a molecular switch involving the viral immediate early (IE) genes was investigated. The IE genes are expressed immediately during cell infection, do not require prior viral protein synthesis for their expression and their expression is mediated by the pool of transcription factors made by the cell, already present at the moment of infection and able to transactivate at the transcriptional level the IE promoters. BoHV-4 IE2 protein (replication and transcription activator homologous, Rta) encoded by open reading frame 50 (ORF 50) is well conserved among $\gamma$-herpesviruses (Zimmermann et al. 2001). Rta expression plays a primary role in initiating viral lytic replication, not only during reactivation of latently infected non-permissive cells but also during de novo infection of permissive cells (van Santen 1993, Sun et al. 1998, Song et al. 2002, Donofrio et al. 2004). The capability of endometrial cells to transactivate the BoHV-4 IE2 promoter was investigated by transient transfection of a fluorescent-labelled IE2 construct. A region of the BoHV-4 (DN599) genome corresponding to the region from nucleotide 61391 to nucleotide 62534 (GenBank accession number AF318571; Zimmermann et al. 2001) was generated by PCR using total DNA isolated from BoHV-4-infected MDBK cells as template and a pair of IE2 promoter primers (sense: $5^{\prime}$-gggaattccatatggccagtgccaagcttttaag$3^{\prime}$; antisense: $5^{\prime}$-gggaactagctagcctgttgttctgctccctttta- $3^{\prime}$ ) containing an artificial Ndel site on the $5^{\prime}$ end and a Nhel site on the $3^{\prime}$ end respectively. One microgram sample DNA was amplified over 35 cycles, each cycle consisting of denaturation at $94{ }^{\circ} \mathrm{C}$ for $1 \mathrm{~min}$, primer annealing at $55^{\circ} \mathrm{C}$ for $1 \mathrm{~min}$ and chain elongation with High Fidelity PCR Enzyme Mix (Fermentas) at $72{ }^{\circ} \mathrm{C}$ for 2 min. PCR amplification was carried out in a final volume of $50 \mu \mathrm{l}$, containing $0.2 \mathrm{mM}$ deoxynucleoside triphosphate and $0.25 \mu \mathrm{M}$ of each primer. In the first cycle, the samples were denatured at $94{ }^{\circ} \mathrm{C}$ for $5 \mathrm{~min}$, and in the last cycle, the extension step was increased to $7 \mathrm{~min}$. The amplicon was column purified, Ndel, Nhel digested and subcloned in pEGFP-C1 vector (Clontech), excised with Ndel and Nhel to remove the CMV promoter and generate the pIE2prom. EGFP construct. Transient transfection using $25 \mu \mathrm{g}$ of the plasmid DNA construct was performed by electroporation, as described above. Endometrial epithelial and stromal cells, BT, BEL, MDBK and BEK cells were electroporated with the reporter construct and monitored every $24 \mathrm{~h}$ by fluorescence microscopy for green cells.

\section{Prostaglandin RIA}

Prostaglandins have a central role in many reproductive functions in mammals (Poyser 1995). Indeed, the duration of ovarian cycles and pregnancy depends on the presence of an active corpus luteum in the ovary, and the life span of the corpus luteum is regulated by the secretion of prostaglandin $\mathrm{F}_{2 \alpha}$ (PGF) and prostaglandin estradiol ( $\left.E_{2} ; \mathrm{PGE}\right)$ from the uterine endometrium. Under physiological conditions, the uterine epithelial cells predominantly secrete PGF when stimulated with oxytocin, whereas the stromal cells produce PGE (Asselin et al. 1996). However, when epithelial or stromal cells are challenged with bacterial LPS, prostaglandin secretion is also stimulated (Herath et al. 2006). As BoHV-4 is isolated from animals with uterine disease, the effect of $24 \mathrm{~h}$ challenge with different amounts of BoHV-4 (10, 1 and 0.1 m.o.i. of virus) or a positive control of $1 \mu \mathrm{g} / \mathrm{ml}$ LPS on endometrial cell function was determined by measuring PGE and PGF in culture supernatants by RIA, as previously described (Cheng et al. 2001, Leung et al. 2001). Samples were diluted in $0.05 \mathrm{M}$ Tris buffer containing $0.1 \%$ gelatine and $0.01 \%$ sodium azide. Standards and tritiated tracers for the PGs were purchased from Sigma and Amersham International PLC (Amersham) respectively. The antisera were a generous gift from Professor N L Poyser (University of Edinburgh, UK) and their cross-reactivity was: $\mathrm{PGF}_{2 \alpha}$ antiserum, $34 \%$ with $\mathrm{PGF}_{1 \alpha}, 25 \%$ with $\mathrm{PGF}_{3 \alpha}$ and $0.54 \%$ with $\mathrm{PGE}_{2} ; \mathrm{PGE}_{2}$ antiserum, $23 \%$ with $\mathrm{PGE}_{1}, 15 \%$ with $\mathrm{PGE}_{3}$ and $0.47 \%$ with $\mathrm{PGF}_{2 \alpha}$ (Poyser 1987). The limits of detection for $\mathrm{PGE}_{2}$ and $\mathrm{PGF}_{2 \alpha}$ were 2 and $1 \mathrm{pg} /$ tube respectively. The intra- and inter-assay coefficients of variation were 4.4 and $7.8 \%$ for $\mathrm{PGE}_{2}$ and 5.1 and $9.7 \%$ for $\mathrm{PGF}_{2 \alpha}$ respectively.

\section{Western blotting}

PGF and PGE are synthesised from arachidonic acid under the regulation of cyclooxygenase 2 (COX-2) isoenzymes in the endometrium (Smith et al. 1996, Arosh et al. 2002). Stromal cells in 6-well culture plates were serum starved overnight, infected with 5 m.o.i. of BoHV-4 in the absence of serum and the cells were collected 1, 2, 4 and $8 \mathrm{~h}$ P.I. to measure COX-2 protein expression by western immunoblotting, with a positive control established by treating 
stromal cells with medium containing 20\% FBS for $1 \mathrm{~h}$. Cell extracts were prepared by adding $100 \mu \mathrm{l} /$ well of cell extraction buffer $(50 \mathrm{mM}$ Tris- $\mathrm{HCl}, 150 \mathrm{mM} \mathrm{NaCl}$ and $1 \%$ NP-40; pH 8). Cell extracts containing $50 \mu$ g total protein were electrophoresed through $12 \%$ SDS-PAGE and transferred to nylon membranes by electroblotting. Membranes were incubated with rabbit anti-COX-2 polyclonal antibody (AB5118; Chemicon International Chandlers Ford, Hampshire, UK), probed with horseradish peroxidase-labelled goat anti-rabbit immunoglobulin $\mathrm{G}_{1}$ $\left(\mathrm{IgG}_{1}\right)$ antibody (A0545, Sigma) and visualised by ECL (ECL Kit; Pierce, Rockford, IL, USA).

\section{The effect of stromal cells on a macrophage cell line persistently infected with BoHV-4}

The persistently infected macrophage cell line (BOMAC/ BoHV-4EGFPATK) was established as previously described (Donofrio \& van Santen 2001) by infecting BOMAC cells, a cell line established from peritoneal macrophages by transformation with simian virus 40 DNA (Stabel \& Stabel 1995). Confluent monolayers of BOMAC cells were inoculated m.o.i. of $1 \mathrm{TCID}_{50} /$ cell) with recombinant BoHV-4 (BoHV-4EGFPATK); by day 3 after inoculation, more than $95 \%$ of cells had detached from the monolayer, leaving behind a small number of cells that did not exhibit CPE. Confluent monolayers established from surviving cells showed $100 \%$ infection, as indicated by the strong fluorescent signal, but without apparent signs of CPE. Also consistent with our previous observations (Donofrio \& van Santen 2001), the persistently infected macrophages produced infectious BoHV-4; medium recovered from BOMAC/BoHV-4EGFP $\Delta$ TK cells inoculated onto BEK cells produced green plaques typical of BoHV-4EGFP $\Delta$ TK. BOMAC/BoHV-4EGFP $\Delta$ TK cells were subcultured at a dilution of 1:2 every 3 days and their growth medium was stored at $-80^{\circ} \mathrm{C}$ for viral titration. The yield of virus in the culture medium on the day the cells were subcultured remained in the range of $4 \times 10^{2} \mathrm{TCID}_{50} /$ $\mathrm{ml}$ throughout the first 20 passages. The macrophages were co-cultured with uninfected stromal cells or control BEK cells, using a transwell approach. After $48 \mathrm{~h}$ of co-culture, the stromal cells or BEK cells in the lower well were analysed under fluorescence microscope for EGFP expression. In addition, the viral titre was measured in the medium from the upper well, where the persistently infected macrophages were located.

\section{Results}

\section{Isolation of pure populations of bovine endometrial stromal and epithelial cells}

The bovine endometrium principally comprises of epithelial cells and stromal cells, but there are also sporadic leukocytes. To study the interaction of BoHV4 with the endometrium, it was important to use purified populations of epithelial and stromal cells without leukocytes, which can influence BoHV-4 function (Donofrio \& van Santen 2001). Endometrial cell cultures were established by the fractional enzyme dissociation method described in Materials and Methods, and there was no mRNA expression of the CD45 pan-leukocyte marker in epithelial or stromal cells (data not shown) as previously described (Herath et al. 2006). The epithelial and stromal cell purity was $>95 \%$ as determined by microscopy (Fig. $1 a$ and $b$ ) and the preferential secretion of PGF and PGE respectively as described previously (Asselin et al. 1996, Herath et al. 2006).

\section{$\mathrm{BoHV}-4$ infects bovine endometrial cells and induces cell death}

To test the susceptibility of bovine endometrial cells to BoHV-4 infection, epithelia and stromal cells were infected with 1 m.o.i. of a recombinant BoHV-4 (BoHV-4EGFPATK) expressing EGFP (Donofrio et al. 2002). A few epithelial cells showed fluorescence $12 \mathrm{~h}$ P.I. (Fig. 2a) and this became generalised by $24 \mathrm{~h}$, with the CPE starting $48 \mathrm{~h} \mathrm{P.I}$. and complete by $72 \mathrm{~h}$. In contrast, most stromal cells were infected by $12 \mathrm{~h}$ P.I. (Fig. 2b), and the CPE started at $24 \mathrm{~h}$ P.I. and was complete by $48 \mathrm{~h}$. To quantify the CPE of BoHV-4 infection, cell survival after challenge with different viral doses was measured using a MTT assay. Epithelial and stromal cells were killed in a dose-dependent manner $48 \mathrm{~h}$ after infection with BoHV-4 and the CPE was greater for stromal than epithelial cells (Fig. 2c). Thus, it appears that BoHV-4 infects both epithelial and stromal cells leading to a CPE, but the stromal cell infection seems to be more efficient.

\section{CPE induced by BoHV-4 in bovine endometrial epithelial and stromal cells is not mediated by apoptosis, but is associated with a productive infection}

BoHV-4 replicates in cell lines or primary cell cultures from a broad spectrum of host species. The infection in some permissive cells leads to viral progeny and a CPE; in other cells, there is a CPE even though no viral progeny are produced, whereas in some non-permissive cells, there is persistent BoHV-4 infection with no effect on cell survival (Donofrio et al. 2000, Gillet et al. 2004). As BoHV-4 infection induced a CPE in endometrial cells, the nature of the cell death and virus production was investigated.

Endometrial epithelial and stromal cells were infected with 5 m.o.i. of BoHV-4 and compared with 5 m.o.i. of BVDV, which is an established apoptotic virus (Schweizer \& Peterhans 2001). The CPE induced by BoHV-4 was not mediated by cell apoptosis as determined by intranucleosomal DNA fragmentation 
(a)

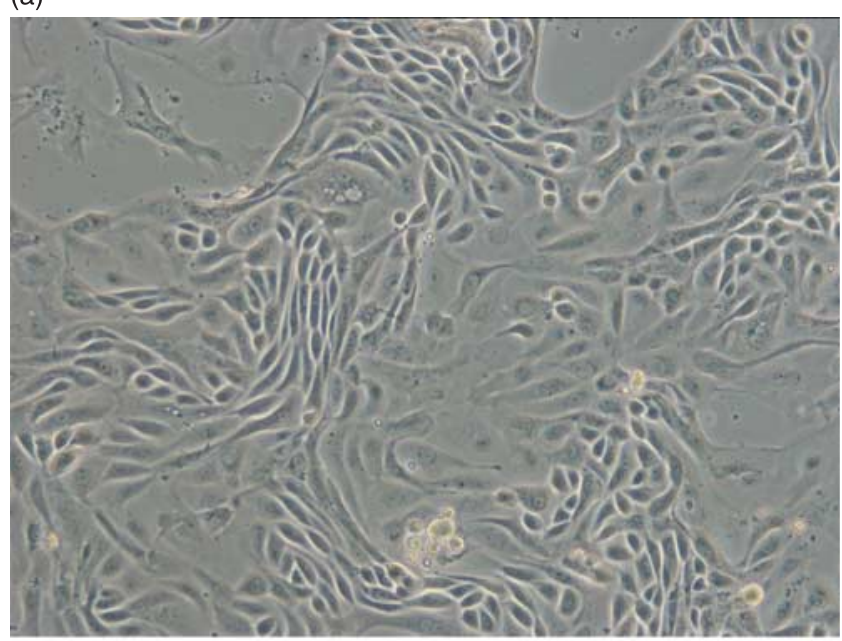

(b)

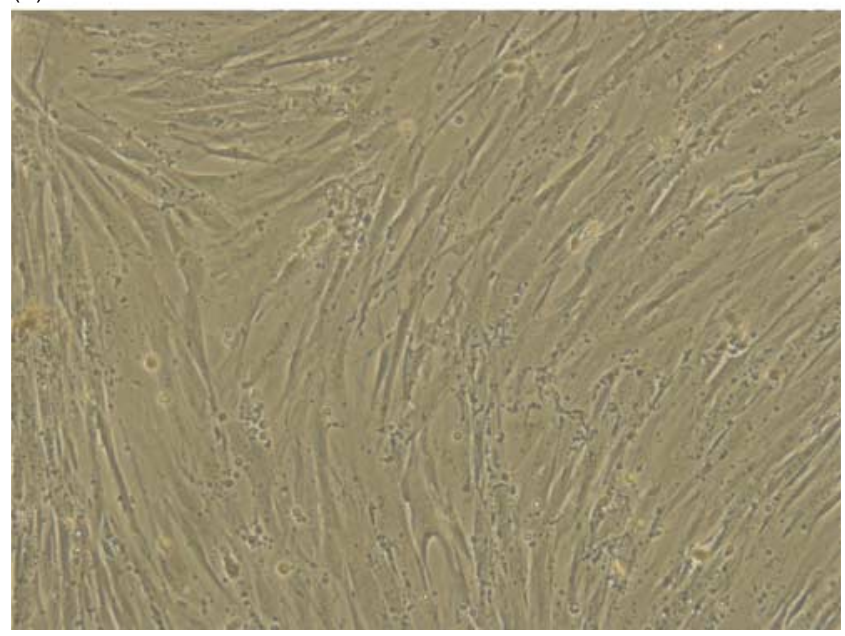

Figure 1 Representative phase contrast images $(10 \times)$ of pure population of (a) bovine endometrial epithelial and (b) stromal cells.

(Fig. 3a) and propidium iodine staining (data not shown), in contrast to the cells infected with BVDV where there was clear DNA fragmentation (Fig. 3a).

Endometrial epithelial and stromal cell viral production was compared with other fully permissive cell types (BT, BEL, MDBK and BEK cells) infected with 1 m.o.i. of BoHV-4EGFP $\Delta$ TK. The viral titres $48 \mathrm{~h}$ P.I. were approximately one log higher for epithelial and two logs higher for stromal cells when compared with the other cell types (Fig. 3b).

\section{Post-viral entry is a determinant step for BoHV-4 replication in endometrial cells}

From the above data, it appears that BoHV-4 has a striking tropism for endometrial cells or that endometrial cells are highly susceptible to BoHV-4 replication. However, viral attachment and penetration do not appear to be critical because many cell types were infected by BoHV-4. To determine which step of the virus life cycle is important for the expression of the tropic phenotype, a reconstitution viral assay was performed. Endometrial epithelial and stromal cells, BT, BEL, MDBK and BEK cells were electroporated with purified BoHV4 EGFP DNA, and the time necessary for the formation of viral plaques was monitored by fluorescence microscopy. Green plaques started to appear by $24 \mathrm{~h}$ after electroporation in epithelial and stromal cells, in contrast to the other cell types where visible green plaques formed between 3 and 5 days after electroporation (Fig. $4 a$ and $b$ ).

\section{$\mathrm{BoHV}$-4 IE2 gene promoter is strongly transactivated in endometrial cells}

To further investigate the mechanisms associated with endometrial tropism, a molecular switch involving the viral IE was investigated using an EGFP-labelled construct containing the IE2 gene (Fig. 5a) electroporated into endometrial epithelial and stromal cells, BT, BEL, MDBK and BEK cells. EGFP started to accumulate robustly as soon as $24 \mathrm{~h}$ after electroporation in the cytoplasm of stromal cells (Fig. 5b) and epithelial cells, in contrast to the other cell types where weak visible green cells appeared not before than 3 days postelectroporation (Fig. 5c).

\section{Low-dose BoHV-4 infection stimulates PGE production in stromal cells}

Under physiological conditions, the uterine epithelial cells predominantly secrete PGF when stimulated with oxytocin, whereas the stromal cells produce PGE (Asselin et al. 1996). The capacity of the endometrial cells to produce PGs in response to BoHV-4 was investigated as BoHV-4 is frequently isolated from the uterus. The cells were capable of responding to pathophysiological challenge as LPS stimulated PGF (Fig. 6a) and PGE (Fig. 6b) secretion from the epithelial and stromal cells respectively as reported previously (Herath et al. 2006). Epithelial cells did not produce PGF in response to BoHV-4 (Fig. 6a). However, stromal cells challenged with 0.1 m.o.i. produced more PGE than untreated controls (Fig. 6b). In contrast, higher viral doses suppressed PGE production, which is likely a consequence of the greater CPE induced by the virus replication.

The rate-limiting enzyme for PGE synthesis in the endometrium is COX-2 (Smith et al. 1996, Arosh et al. 2002). So, as BoHV-4 stimulated PGE secretion by endometrial stromal cells, the induction of COX-2 by BoHV-4 was examined by western blotting and COX-2 was up-regulated as early as $1 \mathrm{~h}$ P.I. (Fig. $6 \mathrm{c}$ ). 


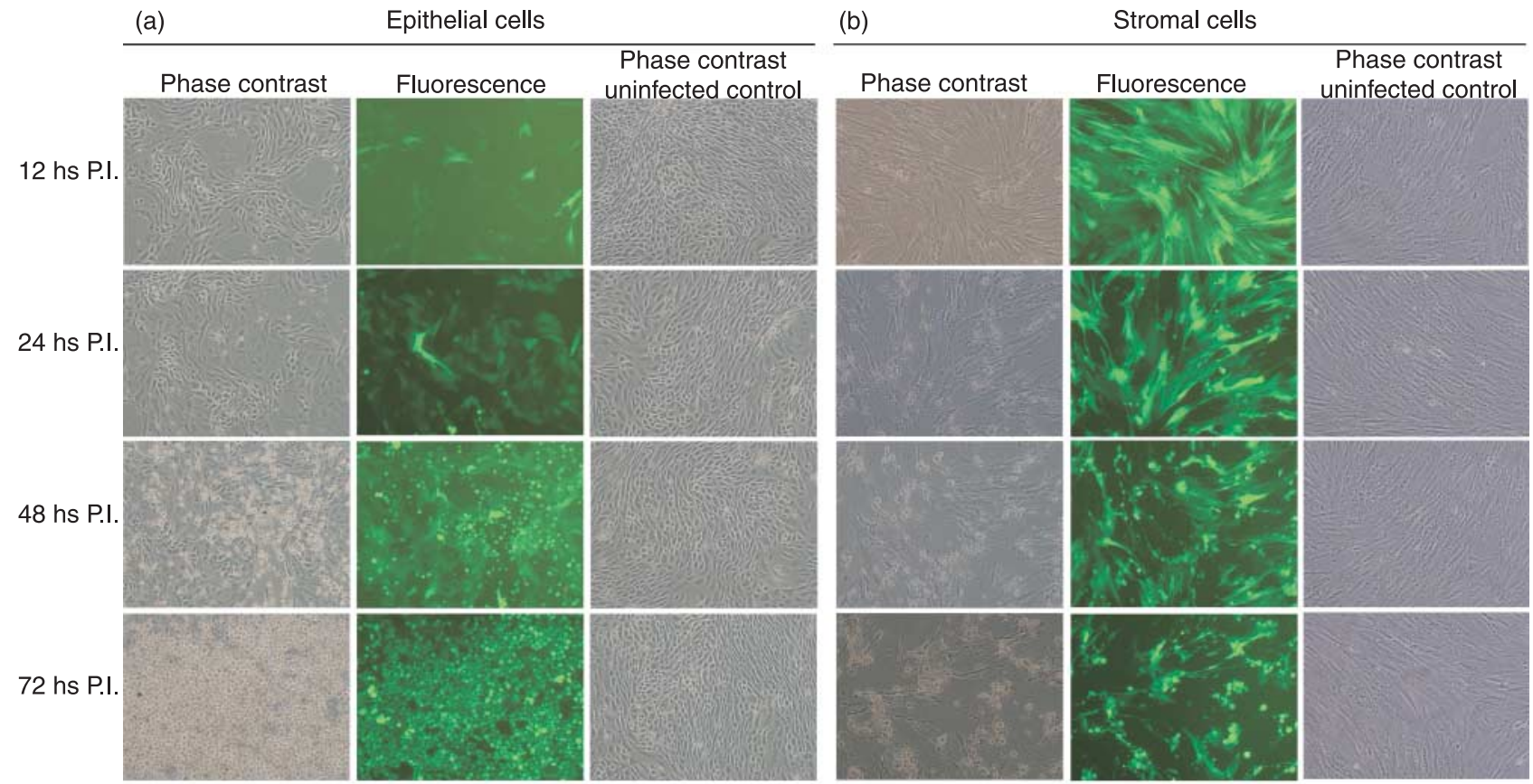

(c)

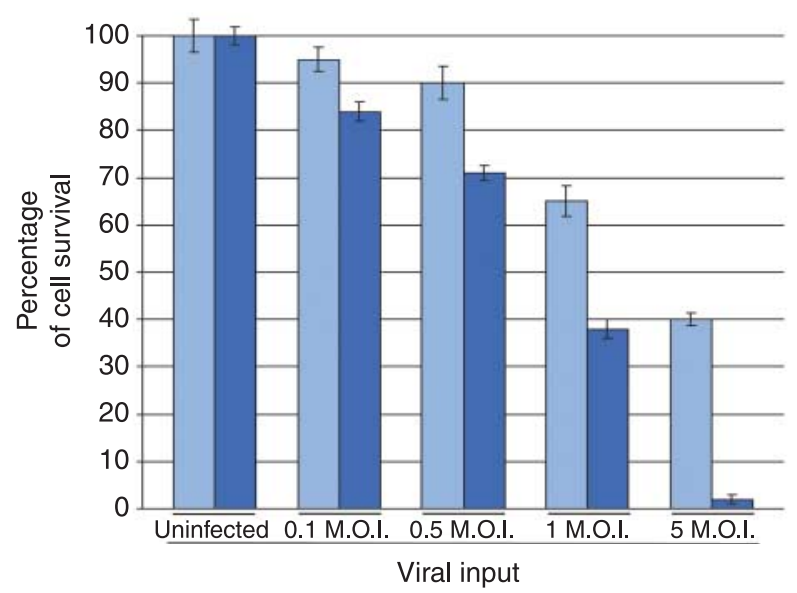

Epithelial

Stromal

Figure 2 Representative fluorescence (green) and phase contrast images (10×) of (a) bovine endometrial epithelial (b) and stromal cells at different times $(12,24,48$ and 72 h) P.I. with 1 m.o.i. of BoHV-4 EGFPATK and the respective phase contrast images of uninfected control. Spreading of the infection can be observed by the green colour invading the field during the time and the CPE is morphologically appreciable by the change of the cell shape, where the cells tend to shrink, becoming rounder and detaching from the flask surface. The experiment was repeated thrice, giving the same result. (c) Assessment of cell survival measured by the reduction of 3-(4, 5-dimethylthiazol-2-yl)-2, 5-diphenyl tetrazolium bromide (MTT) at $48 \mathrm{~h} \mathrm{P.I.}$ Hundred percent of survival was considered the uninfected control. Values are the mean \pm s.D. of three independent experiments $(n=8$ per treatment, $P \geq 0.009$ ).

\section{Endometrial stromal cells enhance BoHV-4 replication in persistently infected macrophages}

As BoHV-4 stimulated stromal cell PGE secretion, a scenario whereby PGE produced by stromal cells could activate BoHV-4 lytic replication in persistently infected macrophages was envisioned: i) Macrophages are the site of persistency of BoHV-4 (Osorio et al. 1985a, 1985b, Lopez et al. 1996, Donofrio \& van Santen 2001); ii) persistently infected macrophages can easily reach the endometrium through the bloodstream and iii) the small amount of BoHV-4 viral particles could infect stromal cells, which will release PGE and reactivate BoHV-4 in persistently infected macrophages. To test the above scenario, stromal cells were co-cultivated with a bovine macrophage cell line persistently infected with BoHV4EGFP $\triangle T K$, producing small amount of infectious viral particles (Donofrio et al. 2005). The effect of stromal cells on BoHV-4 replication in persistently infected 


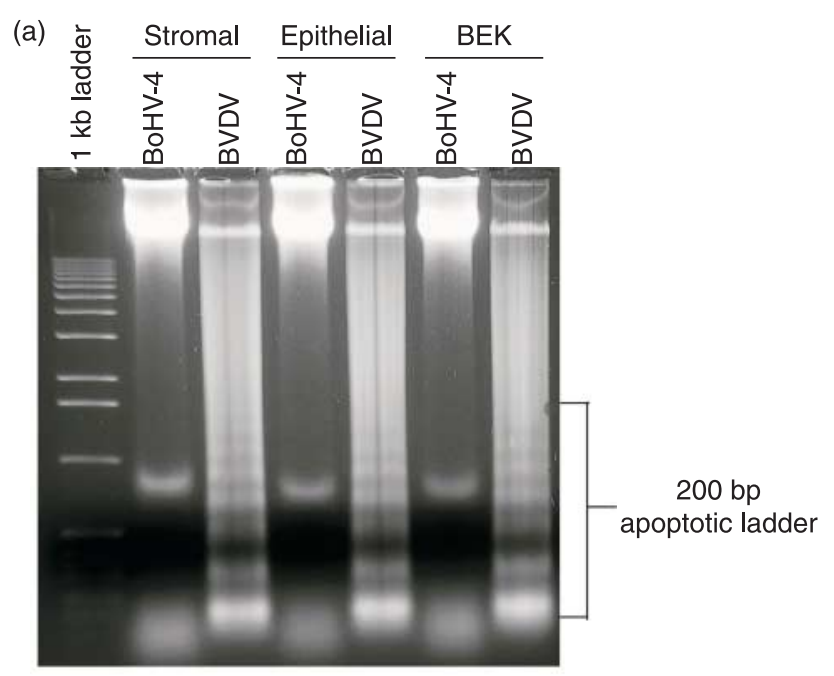

(b)

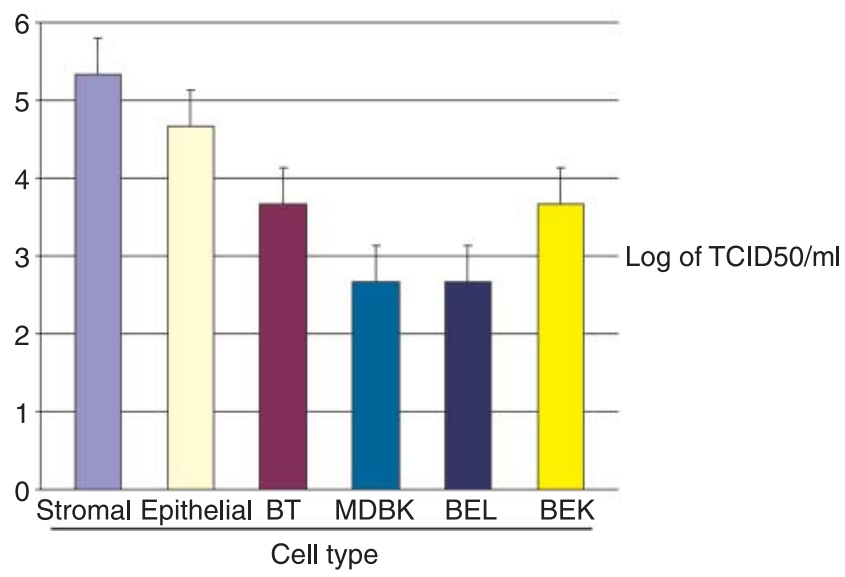

Figure 3 (a) At 72 h P.I, 1.5\% agarose gel electrophoresis of DNA extracts from bovine endometrial epithelial, stromal and control BEK cells, infected with 5 m.o.i. of BoHV-4 and BVDV control virus. (b) Titres of BoHV-4 particles released by different cell types at $48 \mathrm{~h}$ P.I. Values are the mean \pm S.D. of three independent experiments $(n=3$ per treatment, $P \geq 0.05$ ).

macrophages was tested using a transwell approach (Fig. 7a). After $48 \mathrm{~h}$ of co-culture, the stromal cells had a higher level of infection and a higher viral titre in the upper well than the BEK cells (Fig. 7 $a$ and $b$ ). These data support the concept of a symbiotic relationship between the stromal cells and persistently infected macrophages.

\section{Discussion}

Bos taurus is particularly prone to uterine infection and metritis after parturition, which causes considerable infertility and economic loss (Sheldon \& Dobson 2004). The most commonly recognised uterine pathogens are Arcanobacterium pyogenes and Escherichia coli (Griffin et al. 1974, Ruder et al. 1981, Olson et al. 1984, Bonnet et al. 1993, Sheldon \& Dobson 2004). Although viral isolation or serology is not routinely performed in animals with uterine disease, BoHV-4 has been implicated in cases of bovine metritis (Park \& Kendrick 1973, Nilsson 1979, Fortier et al. 1988, Czaplicki \& Thiry 1998, Frazier et al. 2002, Monge et al. 2006). The present study demonstrated a viral tropism by BoHV-4 for the endometrium. The high efficiency of BoHV-4 replication in endometrial cells was associated with strong transactivation of viral IE genes. Furthermore, BoHV-4 increased stromal cell COX-2 protein and stimulated PGE secretion. This viral-induced stromal cell PGE secretion may be a mechanism by which viral replication is stimulated in macrophages, which are the usual repository for persistent bovine infections.

Viruses are restricted to using the metabolic and biosynthetic pathways of the cells that they infect. These pathways vary between cell types, lineage, stage of differentiation and with the state of cell activation. There are many examples of viruses that replicate in specific cells and at particular stages of cell growth, differentiation or activation. This includes the reactivation of cytomegalovirus when host cells differentiate into macrophages; initiation of papillomavirus replication by keratinocytes and replication of minute virus in testicular cells. The key mechanism mediating these effects is the regulation of viral gene expression at the transcriptional level by host cell factors. The present study identified a striking tropism of BoHV-4 for endometrial cells. BoHV-4 efficiently infected purified populations of bovine endometrial stromal and epithelial cells, leading to a non-apoptotic cell death and de novo viral production, which could be an important mechanism underlying the metritis associated with BoHV-4 infection in cattle. The lack of BoHV-4 apoptogenicity found in endometrial cells where BoHV-4 infection was highly productive fits well with the BoHV-4 pro-apoptotic behaviours found in some cell types (Gillet et al. 2005) where BoHV-4 infection is completely unproductive. In a complex multicellular organism, rapid apoptotic cell suicide on virus infection can be seen as an altruist response (Allsopp \& Fazakerley 2000). If it occurs before complete virus replication and assembly, it will be highly effective in limiting viral production. For many viruses, tropism and successful replication are determined by specific cellular receptors that must be engaged for virus binding and entry. However, BoHV-4 can enter many cell types from different species (Donofrio et al. 2002). Furthermore, successful replication of BoHV-4 seems to be governed primarily by post-entry events as shown by the fast viral reconstitution following the electroporation of nude viral DNA into the cells. The ORF 50 gene product, also known as the replication and transcription activator (Rta), is an IE gene which is well conserved among all $\gamma$-2 herpesviruses. BoHV-4 IE2 RNA is the less abundant, spliced, $1.8 \mathrm{~kb}$ RNA, which is transcribed from the left to 
the right on the restriction map of the BoHV-4 genome and contained in the $8.3 \mathrm{~kb}$ Hind III fragment F (van Santen 1993). The predicted amino acid sequence of the protein encoded by IE2 RNA reveals that it could encode a $61 \mathrm{kDa}$ protein with amino acid sequence homology to the Epstein-Barr virus transactivator $\mathrm{R}$ and its homologue including herpesvirus saimiri, equine herpesvirus 2, murine herpesvirus 68 and Kaposi's sarcoma-associated (a)

$$
1 \text { day }
$$

$$
\text { P.T. }
$$

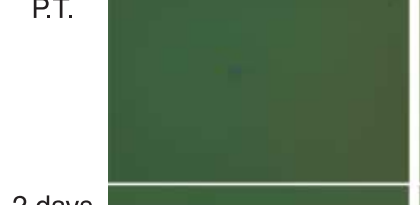

$$
\begin{aligned}
& 2 \text { days } \\
& \text { P.T. }
\end{aligned}
$$

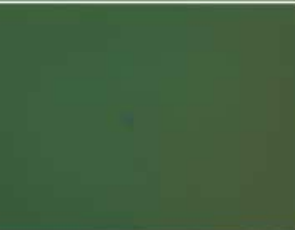

3 days
P.T.

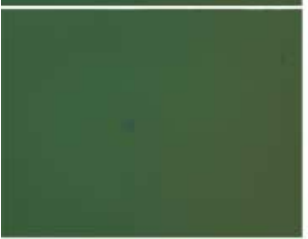

$$
\begin{aligned}
& 4 \text { days } \\
& \text { P.T. }
\end{aligned}
$$

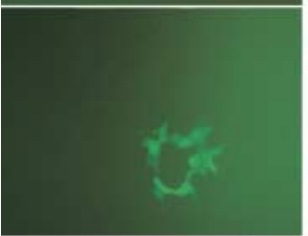

5 days P.T.

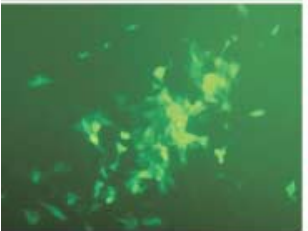

(b)

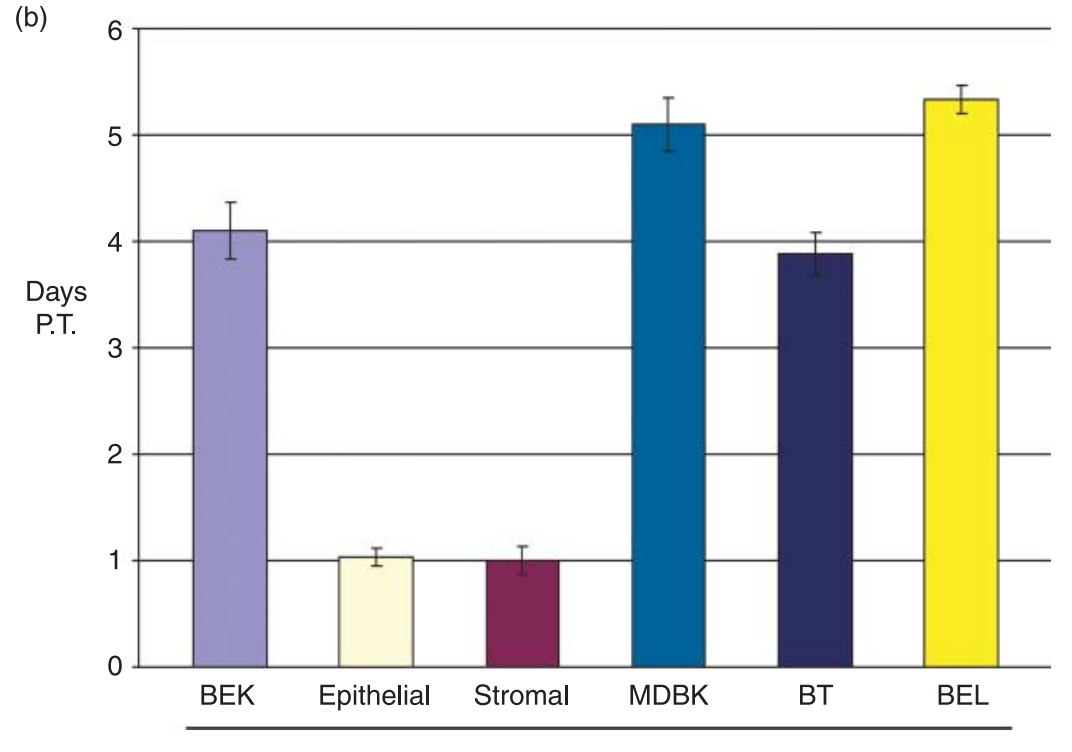

Cell type

Epithelial
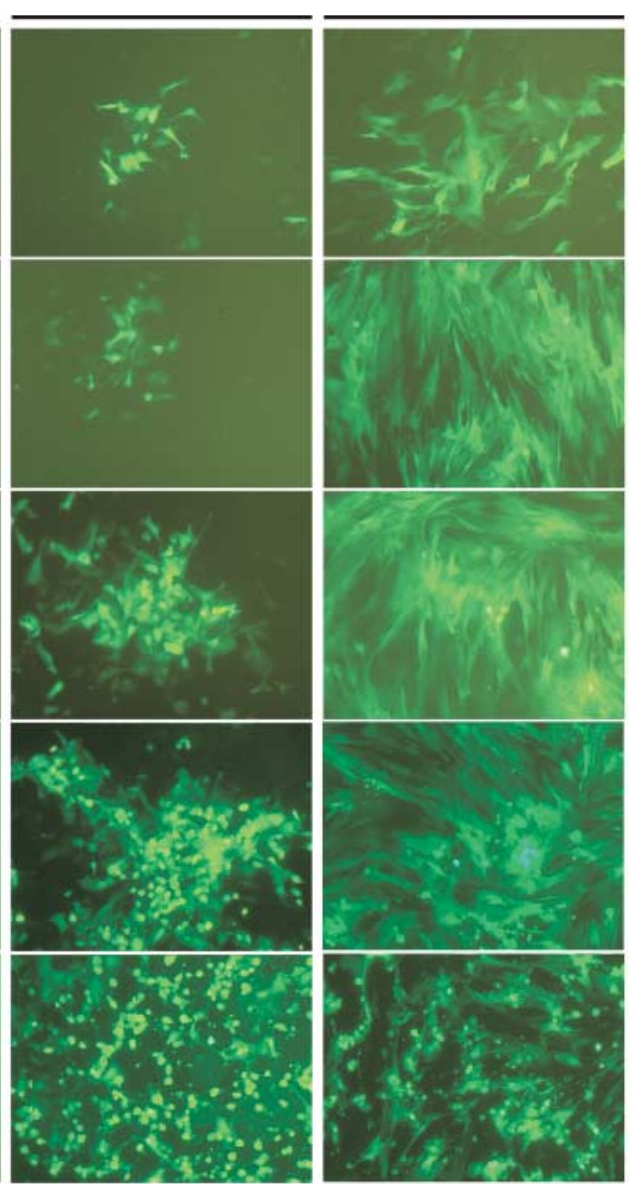

Figure 4 (a) BoHV-4 plaques obtained at different times $(1,2,3,4$ and 5 days) post-electroporation (P.E.) of nude BoHV-4EGFPATK DNA in different cell types. Images are representative of bovine epithelial, stromal and BEK cells. (b) Graph bars summarising the time necessary for plaques formation in different cell types (endometrial epithelial cells, endometrial stromal cells, BT, BEL, MDBK and BEK cells). Values are the mean \pm s.D. of three independent experiments $(n=3$ per treatment, $P \geq 0.05)$. 
(a)

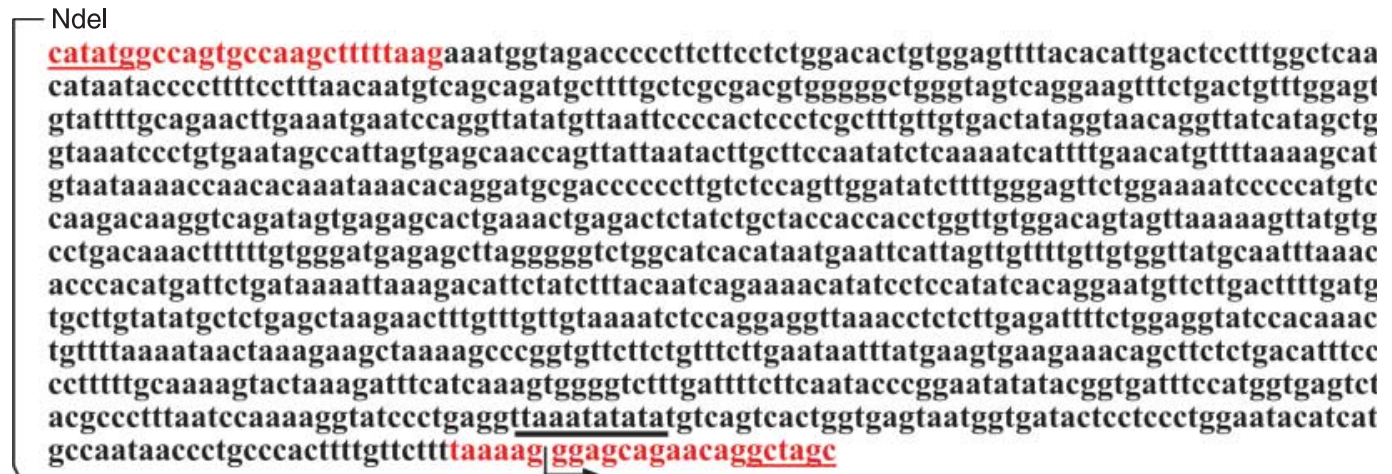
- gecataacectgeceactttgttctttaaaag|ggagcagaacagectagc

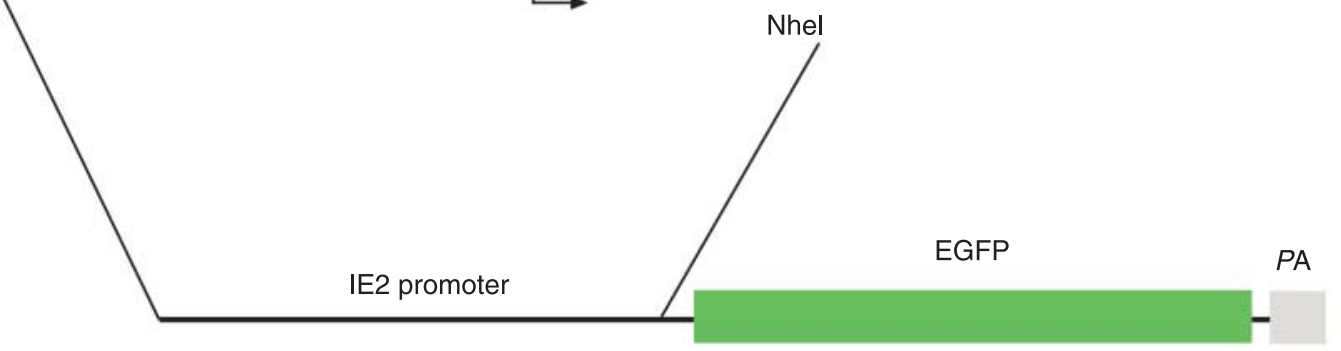

(b)
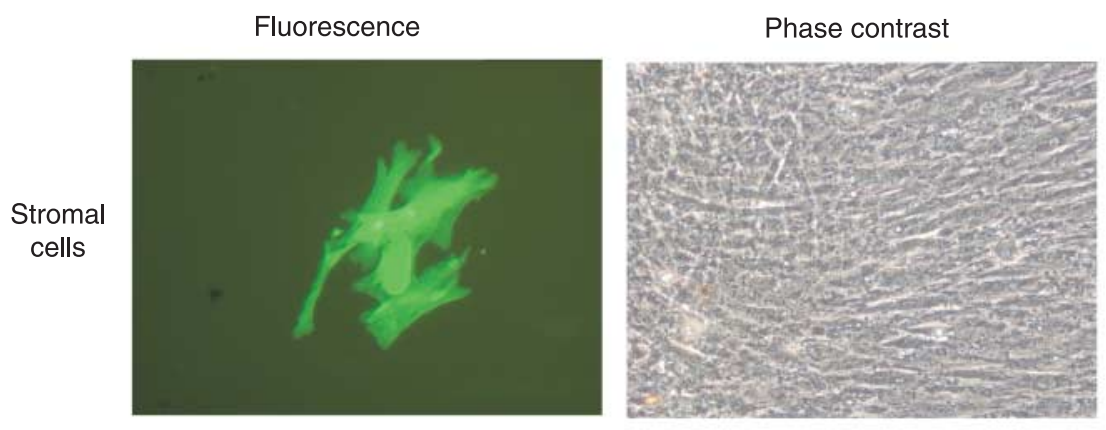

(c)

\begin{tabular}{|l|c|c|c|}
\multicolumn{1}{c}{ Cell type } & $24 \mathrm{hs}$ & $48 \mathrm{hs}$ & $72 \mathrm{hs}$ \\
\cline { 2 - 4 } \multicolumn{1}{c|}{} & - & - & + \\
\hline MDBK & - & - & + \\
\hline BEK & - & - & + \\
\hline BT & - & - & + \\
\hline BEL & + & & \\
\hline Stromal & + & & \\
\hline Epithelial & + & & \\
\hline
\end{tabular}

Figure 5 (a) Diagram showing the 1143 bp IE2 promoter sequence containing the putative TATA box (underlined in black) and the first 15 non-coding nucleotides of the first exon. Sense and antisense primers used for the PCR amplification are in red and contain the Ndel and Nhel restriction sites (underlined in red) respectively for sub-cloning of the amplicon in front of the EGFP ORF (green box) followed by the bovine growth hormone polyadenylation signal (pA (grey box)). (b) Representative fluorescence and phase contrast images of transfected endometrial stromal cells with the above-described construct and expressing EGFP $24 \mathrm{~h}$ post-transfection. (c) Summarising schema of the time necessary for EGFP accumulation into the different cell types (endometrial epithelial cells, endometrial stromal cells, BT, BEL, MDBK and BEK cells), following transfection with the abovedescribed construct. Values are the mean of three independent experiments ( $n=3$ and $P \geq 0.05$ ). 
(a)

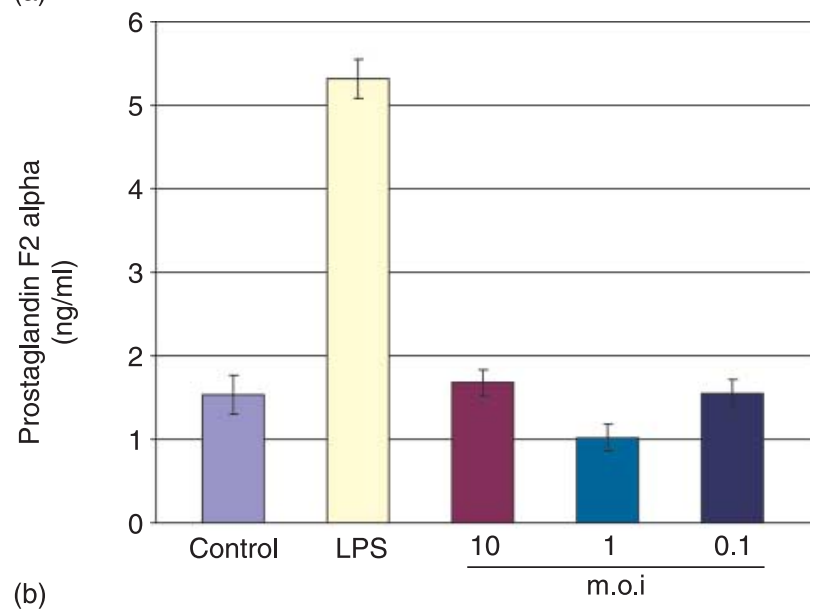

(b)

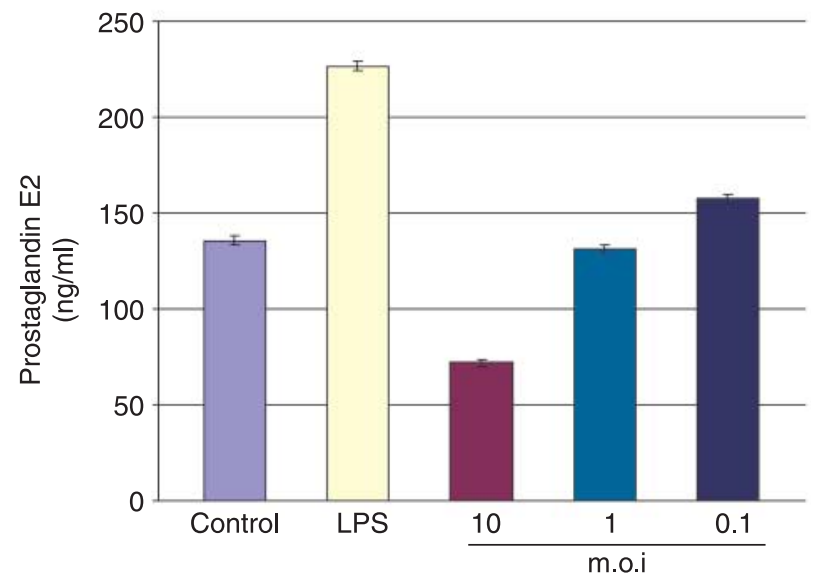

(c)

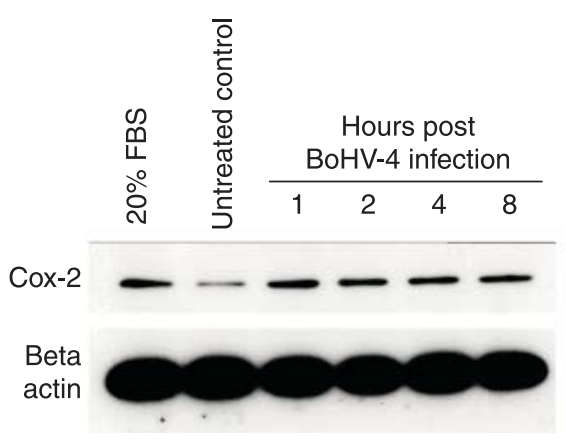

Figure 6 Prostaglandin production by (a) epithelial and (b) stromal cells after challenge with LPS $(1 \mu \mathrm{g} / \mathrm{ml})$ or BoHV-4 at the different m.o.i. indicated. After $24 \mathrm{~h}$ in culture, supernatants were harvested and prostaglandin production was measured by RIA. Values are presented as the mean \pm s.D. of three independent experiments. Differences were statistically different at $P<0.05$ when compared with a media control. (c) Western immunoblotting of endometrial stromal cell extracts and infection with BoHV-4 EGFPATK. Positive control was established treating cells with medium containing $20 \%$ of FBS. $\beta$-Actin as the loading control. The same experiment was repeated thrice, giving the same results.

herpesvirus. Transactivation studies have shown that BoHV-4 IE2 protein specifically transactivates expression of a reporter gene linked to the promoter regulatory region of the BoHV-4 early $(E)$ gene encoding the (a)

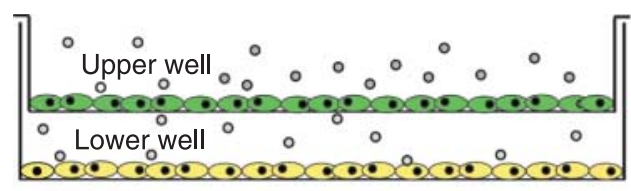

- Virus

BoHV-4 persistently infected cells

Stromal or BEK cells

(b)

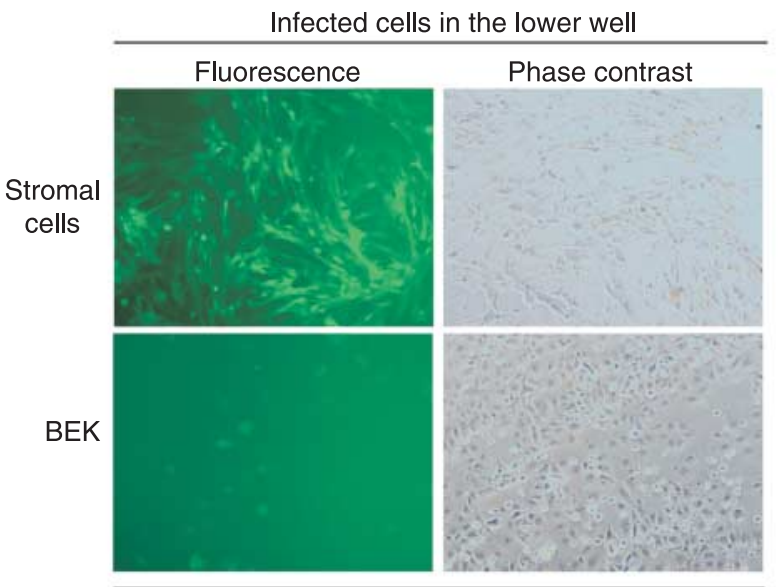

$48 \mathrm{~h}$ post co-cultivation

(c)

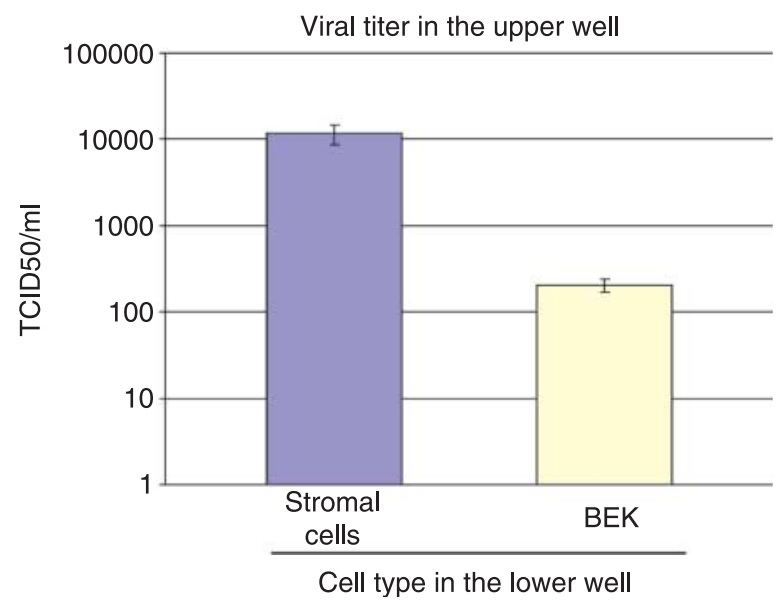

Figure 7 (a) Schematic illustration of the transwell model used for co-culturing BoHV-4EGFP $\Delta$ TK persistently infected bovine macrophage cell line (in green in the upper well), producing low amount of infectious virus (grey dots) with bovine endometrial stromal or control BEK cells (in yellow) seated in the lower well. The transwell consists of a permeable membrane and allows diffusion of the viral particles. (b) Fluorescence and phase contrast images of bovine endometrial stromal and control BEK cells seated in the lower well at $48 \mathrm{~h}$ post co-cultivation. (c) Graph bar of the viral titre in the upper well. Values are the mean \pm s.D. of three independent experiments ( $n=3$ and $P \geq 0.05)$.

BoHV-4 homologue of herpes simplex virus type 1 major DNA-binding protein (van Santen 1991). The BoHV-4 ORF 50 homologues have been shown to play a pivotal role in regulating the lytic switch in a 
non-permissive cell line following their overexpression (Donofrio et al. 2004). Indeed, in the present study, IE2 promoter transactivation in endometrial cells triggered the BoHV-4 phenotype in those cells, as shown by the fast up-regulation of EGFP reporter gene expression driven by IE2 promoter. Interestingly, a preliminary analysis of the BoHV-4 IE2 promoter by Tfsitescan/ dynamicPlus server reveals five positive regulatory elements that are also found in the rabbit uteroglobin promoter and apparently specific for endometrial cells. The most surprising similarity was found for the responsive element close to the TATA box, which may indicate the existence of an endometrial-specific TATA box (Misseyanni et al. 1991). A comparison with the promoters of two other endometrium-specific genes, the rat homologous to rabbit uteroglobin (Hagen et al. 1990) and the pig uteroferrin gene (Simmen et al. 1989) indicates that this TATA box element is well conserved. Further studies are needed to identify the nature of the factors in bovine endometrial cells and how they interact with BoHV-4 IE2 promoter.

Specific enhancers and transcriptional activators produced by host cells are important to initiate and maintain viral replication. In persistently infected macrophages, BoHV-4 replication is stimulated by the addition of exogenous PGE (Donofrio etal. 2005). Bovine endometrial cells induce COX-2 and PGE production in response to a number of cell activators and inflammatory signals, such as LPS (Herath et al. 2006). Taken together, these observations support a scenario where viral particles infecting the endometrium could stimulate PGE production and establish a positive-feedback loop between PGE production and viral replication (Donofrio et al. 2005). That model of BoHV-4-induced metritis seems to be supported in the present ex vivo study by the observations that bovine endometrial stromal cells produced PGE following BoHV4 infection and cells persistently infected with BoHV-4 were reactivated after co-cultivation with endometrial stromal cells using a transwell approach. Infections by several viruses, including many herpesviruses, such as herpes simplex virus, human cytomegalovirus, EpsteinBarr virus and murine $\gamma$-herpesvirus 68 have been reported to alter COX-2 expression (Reynolds \& Enquist 2006). In fact, rhesus cytomegalovirus even encodes a COX-2 homologue in its genome, emphasising the importance of this enzyme (Hansen et al. 2003). In addition, many studies have examined the regulation of COX-2 expression and $\mathrm{PGE}_{2}$ production during viral infection as well as the effect of $\mathrm{PGE}_{2}$ production on viral replication and virulence (Steer \& Corbett 2003). Prostaglandins are potent mediators of many critical physiological and inflammatory responses, and they modulate the host defence against various pathogens. They suppress some innate immune factors, including nitric oxide (NO) production, and have effects on the acquired immune response, specifically by suppressing the Th1 response. For instance, $\mathrm{PGE}_{2}$ can inhibit the production of $\gamma$-interferon by activated human $T$ cells in vitro (Snijdewint et al. 1993) and that of Th1 cytokines such as interleukin-12 in vivo (Newberry et al. 1999, Kuroda et al. 2000). In addition to inhibiting the production of Th1 cytokines, $\mathrm{PGE}_{2}$ switches the immune response towards a Th2 response, which is less effective in mounting an antiviral response (Betz \& Fox 1991, Kuroda et al. 2000). PGE is one of the most potent and abundant PGs present during inflammatory reactions (Appleton et al. 1996). The very early host responses to viral infections are usually non-specific and include the induction of cytokines such as interferons and tumour necrosis factor- $\alpha$. NO synthase (NOS) is an interferon-inducible protein that is activated during innate immune responses (Reiss \& Komatsu 1998). When present at high concentrations after the expression of the inducible isoform of NOS (iNOS), NO functions as a cytotoxic molecule, reacting with proteins or $\mathrm{H}_{2} \mathrm{O}_{2}$ to form a highly toxic compound called peroxynitrite $\left(\mathrm{ONOO}^{-}\right.$; Reiss \& Komatsu 1998). $\mathrm{NO}$ is also thought to participate in the antiviral response to infection by attenuating the replication of both DNA and RNA viruses (Reiss \& Komatsu 1998). The products of COX and NOS enzymes, PGs and NO, have been shown to share an antagonistic relationship with one another. The inhibition of COX activity in vesicular stomatitis virus (VSV)-infected cells causes a reduction in viral propagation and a concordant increase in extracellular NO levels. Treatment with an iNOS inhibitor, L-NAME or exogenous $\mathrm{PGE}_{2}$ in the presence of COX inhibitors can restore VSV growth and decrease $\mathrm{NO}$ production, underscoring a role for PGs in counteracting the antiviral effects of NO (Chen et al. 2000). Besides their role in immunomodulation and counteraction of the antiviral effects of NO, PGs have been shown to be involved in modulating transcription from viral promoters. The human immunodeficiency virus type 1 (HIV-1) long terminal repeat (LTR) contains sequences that are important for DNA integration, as well as signals, such as an internal polymerase II promoter, which are necessary for the transcription of the integrated retroviral DNA. PGE $_{2}$ can increase transcription driven by the HIV-1 LTR in T lymphocytes (Dumais etal. 1998). Transcription of one of the IE (IE2) of HCMV was reduced in cells that were treated with COX-2 inhibitors. Therefore, a potential role for COX induction in the context of a virus infection is the activation of transcription from viral promoters via PGs.

In the case of BoHV-4 persistently infected animals, stromal cell PGE secretion may reactivate viral replication, which in turn would lead to endometrial inflammation. Bacterially induced metritis in cattle persistently infected with BoHV-4 could possibly be exacerbated or become chronic following the recruitment from the bloodstream to the site of inflammation of macrophages persistently infected with BoHV-4. This theory could explain the fact that BoHV-4 can be isolated from a healthy animal too, where in the absence of inflammation, the pathogenic potential of BoHV-4 is ameliorated. 
In conclusion, the present study indicates that BoHV-4 is a likely pathogen associated with uterine disease. The virus is tropic for endometrial epithelial and stromal cells, causing a rapid CPE. It appears that the endometrial cells rapidly induce IE gene expression and viral replication. Furthermore, there was a symbiotic relationship between stromal cell PGE secretion in response to BoHV-4 and reactivation of viral replication in macrophages. These data provide evidence of cellular and molecular mechanisms underlying the observation of uterine disease in animals with BoHV-4.

\section{Acknowledgements}

We thank the Italian Minister of Science (Italian National Grant MIUR, PRIN 2005, 2005078885) and BBSRC (Grant 48/S19795) for financial support. The authors declare that there is no conflict of interest that would prejudice the impartiality of this scientific work.

\section{References}

Allsopp TE \& Fazakerley JK 2000 Altruistic cell suicide and the specialized case of the virus-infected nervous system. Trends in Neurosciences 23 284-290.

Appleton I, Tomlinson A \& Willoughby DA 1996 Induction of cyclooxygenase and nitric oxide synthase in inflammation. Advances in Pharmacology 35 27-78.

Arosh JA, Parent J, Chapdelaine P, Sirois J \& Fortier MA 2002 Expression of cyclooxygenases 1 and 2 and prostaglandin E synthase in bovine endometrial tissue during the estrous cycle. Biology of Reproduction 67 161-169.

Asselin E, Goff AK, Bergeron H \& Fortier MA 1996 Influence of sex steroids on the production of prostaglandins F2 alpha and E2 and response to oxytocin in cultured epithelial and stromal cells of the bovine endometrium. Biology of Reproduction 54 371-379.

Bartha A, Juhasz M \& Liebermann H 1966 Isolation of a bovine herpesvirus from calves with respiratory disease and keratoconjuntivitis. Acta Veterinaria Academiae Scientiarum Hungaricae $\mathbf{1 6}$ 357-358.

Betz M \& Fox BS 1991 Prostaglandin E2 inhibits production of Th1 lymphokines but not of Th2 lymphokines. Journal of Immunology 146 108-113.

Bonnett BN, Martin SW \& Meek AH 1993 Associations of clinical findings, bacteriological and histological results of endometrial biopsy with reproductive performance of postpartum dairy cows. Preventive Veterinary Medicine 15 205-220.

Bublot M, Lomonte P, Lequarre AS, Albrecht JC, Nicholas J, Fleckenstein B, Pastoret PP \& Thiry E 1992 Genetic relationships between bovine herpesvirus 4 and the gammaherpesviruses EpsteinBarr virus and herpesvirus saimiri. Virology 190 654-655.

Castrucci G, Frigeri F, Cilli V, Donelli G, Ferrari M, Chicchinri U \& Bordoni E 1986 A study of herpesvirus isolated from dairy cattle with a history of reproductive disorders. Comparative Immunology Microbiology and Infectious Diseases 9 13-21.

Castrucci G, Frigeri F, Ferrari M, Ranucci S, Aldrovandi V, Cilli V, Rampichini L \& Gatti R 1987 Experimental infection of calves with strain of bovid herpesvirus-4. Comparative Immunology Microbiology and Infectious Diseases 10 41-49.

Ceserman E, Moore PS, Rao PH, Inghirami G, Knowles DM \& Chang Y 1995 In vitro establishment and characterization of two acquired immunodeficiency syndrome-related lymphoma cell lines (BC-1 and BC-2) containing Kaposi's sarcoma-associated herpesvirus-like (KSHV) DNA sequences. Blood 86 2708-2714.

Chen N, Warner JL \& Reiss CS 2000 NSAID treatment suppresses VSV propagation in mouse CNS. Virology 276 44-51.

Cheng Z, Robinson RS, Pushpakumara PG, Mansbridge RJ \& Wathes DC 2001 Effect of dietary polyunsaturated fatty acids on uterine prostaglandin synthesis in the cow. Journal of Endocrinology 171 463-473.

Czaplicki G \& Thiry E 1998 An association exists between bovine herpesvirus-4 seropositivity and abortion in cows. Preventive Veterinary Medicine 33 235-240.

Dewals B, Gillet L, Gerdes T, Taracha EL, Thiry E \& Vanderplasschen A 2005 Antibodies against bovine herpesvirus 4 are highly prevalent in wild African buffaloes throughout eastern and southern Africa. Veterinary Microbiology 110 209-220.

Donofrio G \& van Santen VL 2001 A bovine macrophage cell line supports bovine herpesvirus 4 persistent infection. Journal of General Virology 82 1181-1185.

Donofrio G, Cavirani S \& van Santen VL 2000 Establishment of a cell line persistently infected with bovine herpesvirus 4 using a recombinant virus. Journal of General Virology 81 1807-1814.

Donofrio G, Cavirani S, Taddei S \& van Santen VL 2002 Bovine herpesvirus 4 as a gene delivery vector. Journal of Virological Methods 101 49-61.

Donofrio G, Cavirani S, Taddei S \& Flammini CF 2004 Activation of bovine herpesvirus 4 lytic replication in a non-permissive cell line by over expression of BoHV-4 immediate early (IE) 2 gene. Journal of Virological Methods 116 203-207.

Donofrio G, Cavirani S, van Santen VL \& Flammini CF 2005 Potential secondary pathogenic role for bovine herpesvirus 4. Journal of Clinical Microbiology 43 3421-3426.

Dubuisson J, Thiry E, Thalasso F, Bublot M \& Pastoret PP 1988 Biological and biochemical comparison of bovid herpesvirus-4 strains. Veterinary Microbiology 16 339-349.

Dubuisson J, Thiry E, Bublot $M$, Thomas I, van Bressem MF, Coignoul F \& Pastoret PP 1989 Experimental infection of bulls with a genital isolate of bovine herpesvirus-4 and reactivation of latent virus with dexamethasone. Veterinary Microbiology 21 97-114.

Dumais N, Barbeau B, Olivier M \& Tremblay MJ 1998 Prostaglandin E2 up-regulates HIV-1 long terminal repeat-driven gene activity in $T$ cells via NF-kappaB-dependent and -independent signaling pathways. Journal of Biological Chemistry 273 27306-27314.

Egyed L 1998 Replication of bovine herpesvirus type 4 in human cells in vitro. Journal of Clinical Microbiology 36 2109-2111.

Flore O, Rafii S, Ely S, O'Leary JJ, Hyjek EM \& Cesarman E 1998 Transformation of primary human endothelial cells by Kaposi's sarcoma-associated herpesvirus. Nature 394 588-592.

Fortier MA, Guilbault LA \& Grasso F 1988 Specific properties of epithelial and stromal cells from the endometrium of cows. Journal of Reproduction and Fertility 83 239-248.

Frazier K, Pence M, Mauel MJ, Liggett A, Hines ME, Sangster L, Lehmkuhl HD, Miller D, Styer E, West J \& Baldwin CA 2001 Endometritis in postparturient cattle associated with bovine herpesvirus-4 infection: 15 cases. Journal of Veterinary Diagnostic Investigation 13 502-508.

Frazier KS, Baldwin CA, Pence M, West J, Bernard J, Liggett A, Miller D \& Hines ME 2002 Seroprevalence and comparison of isolates of endometriotropic bovine herpesvirus-4. Journal of Veterinary Diagnostic Investigation 14 457-462.

Gillet L, Minner F, Detry B, Farnir F, Willems L, Lambot M, Thiry E, Pastoret PP, Schynts F \& Vanderplasschen A 2004 Investigation of the susceptibility of human cell lines to bovine herpesvirus 4 infection: demonstration that human cells can support a nonpermissive persistent infection which protects them against tumor necrosis factor $\boldsymbol{\alpha}$-induced apoptosis. Journal of Virology 78 2336-2347.

Gillet L, Dewals B, Farnir F, de Leval L \& Vanderplasschen A 2005 Bovine herpesvirus 4 induces apoptosis of human carcinoma cell lines in vitro and in vivo. Cancer Research 65 9463-9472. 
Griffin JF, Hartigan PJ \& Nunn WR 1974 Non-specific uterine infection and bovine fertility. I. Infection patterns and endometritis during the first seven weeks post-partum. Theriogenology 1 91-106.

Hagen G, Wolf M, Katyal SL, Singh G, Beato M \& Suske G 1990 Tissuespecific expression, hormonal regulation and $5^{\prime}$-flanking gene region of the rat Clara cell $10 \mathrm{kDa}$ protein: comparison to rabbit uteroglobi. Nucleic Acids Research 18 2939-2946.

Hansen SG, Strelow LI, Franchi DC, Anders DG \& Wong SW 2003 Complete sequence and genomic analysis of rhesus cytomegalovirus. Journal of Virology 77 6620-6636.

Herath S, Fischer DF, Werling D, Williams EJ, Lilly ST, Dobson H, Bryant CE \& Sheldon IM 2006 Expression and function of toll-like receptor 4 in the endometrial cells of the uterus. Endocrinology 147 562-570.

Ireland JJ, Murphee RL \& Coulson PB 1980 Accuracy of predicting stages of bovine estrous cycle by gross appearance of the corpus luteum. Journal of Dairy Science 63 155-160.

Jung JU, Choi JK, Ensser A \& Biesinger B 1999 Herpesvirus saimiri as a model for gammaherpesvirus oncogenesis. Seminars in Cancer Biology 9 231-239.

Kim JJ \& Fortier MA 1995 Cell type specificity and protein kinase C dependency on the stimulation of prostaglandin E2 and prostaglandin F2 alpha production by oxytocin and platelet-activating factor in bovine endometrial cells. Journal of Reproduction and Fertility 103 239-247.

Krogman LA \& McAdaragh JP 1982 Recrudescence of bovine herpesvirus-5 in experimentally infected calves. American Journal of Veterinary Research 43 336-338.

Kuroda E, Sugiura T, Zeki K, Yoshida Y \& Yamashita U 2000 Sensitivity difference to the suppressive effect of prostaglandin E2 among mouse strains: a possible mechanism to polarize Th2 type response in BALB/c mice. Journal of Immunology 164 2386-2395.

Leung ST, Cheng Z, Sheldrick EL, Derecka K, Flint AP \& Wathes DC 2001 The effects of lipopolysaccharide and interleukins- 1 alpha, -2 and -6 on oxytocin receptor expression and prostaglandin production in bovine endometrium. Journal of Endocrinology 168 497-508.

Lomonte P, Bublot M, vanSanten VL, Keil G, Pastoret PP \& Thiry E 1996 Bovine herpesvirus 4: genomic organization and relationship with two other gammaherpesviruses, Epstein-Barr virus and herpesvirus saimiri. Veterinary Microbiology 53 79-89.

Lopez OJ, Galeotta J \& Osorio FA 1996 Bovine herpesvirus type-4 (BHV-4) persistently infects cells of the marginal zone of spleen in cattle. Microbial Pathogenesis 21 47-58.

Mehrotra ML, Shucla DC \& Srivastava NC 1986 Isolation of a new herpesvirus from cases of reproductive disorders in cow. Indian Journal of Animal Sciences $\mathbf{5 6}$ 1196-1199.

Miller G, Heston L, Grogan E, Gradoville L, Rigsby M, Sun R, Shedd D, Kushnaryov VM, Grossberg S \& Chang Y 1997 Selective switch between latency and lytic replication of Kaposi's sarcoma herpesvirus and Epstein-Barr virus in dually infected body cavity lymphoma cells. Journal of Virology 71 314-324.

Misseyanni A, Klug J, Suske G \& Beato M 1991 Novel upstream elements and the TATA-box region mediate preferential transcription from the uteroglobin promoter in endometrial cells. Nucleic Acids Research 19 2849-2859.

Mohanty SB, Hammond RC \& Lillie MG 1971 A new bovine herpesvirus and its effect on experimentally infected calves. Archiv Für Die Gesamte Virusforschung 34 394-395.

Monge A, Elvira L, Gonzalez JV, Astiz S \& Wellenberg GJ 2006 Bovine herpesvirus 4-associated postpartum metritis in a Spanish dairy herd. Research in Veterinary Science 80 120-125.

Moses AV, Fish KN, Ruhl R, Smith PP, Strussenberg JG, Zhu L, Chandran B \& Nelson JA 1999 Long-term infection and transformation of dermal microvascular endothelial cells by human herpesvirus 8. Journal of Virology 73 6892-6902.

Naeem K, Caywood DD, Goyal SM, Werdin RE \& Murtaugh MP 1993 Persistence of bovid herpesvirus-4 in experimentally inoculated pregnant rabbits. New Microbiologica 16 87-93.
Newberry RD, Stenson WF \& Lorenz RG 1999 Cyclooxygenase-2dependent arachidonic acid metabolites are essential modulators of the intestinal immune response to dietary antigen. Nature Medicine 5 900-906.

Nikolin V, Donofrio G, Milošević B, Taddei S, Radosavljević V \& Milićević V 2007 First Serbian isolates of bovine herpesvirus 4 (BoHV-4) from a herd with history of postpartum metritis. New Micribiologica 30 53-57.

Nilsson K 1979 The nature of lymphoid cell lines and their relationship to the virus. In The Epstein-Barr Virus, pp 225-281. Eds MA Epstein \& BG Achong. Berlin: Verlag.

Olson JD, Ball L, Mortimer RG, Farin PW, Adney WS \& Huffman EM 1984 Aspects of bacteriology and endocrinology of cows with pyometra and retained foetal membranes. American Journal of Veterinary Research 45 2251-2255.

Osorio FA \& Reed DE 1983 Experimental inoculation of cattle with bovine herpesvirus-4: evidence for a lymphoid-associated persistent infection. American Journal of Veterinary Research 44 975-980.

Osorio FA, Reed DE \& Rock DL 1982 Experimental infection of rabbits with bovine herpesvirus-4: acute and persistent infection. Veterinary Microbiology 7 503-513.

Osorio FA, Reed DE, Van Der Maaten MJ \& Metz CA 1985a Comparison of the herpesviruses of cattle by restriction endonuclease analysis and serologic analysis. American Journal of Veterinary Research 46 2104-2109.

Osorio FA, Rock DL \& Reed DE $1985 b$ Studies on the pathogenesis of a bovine cytomegalo-like virus in an experimental host. Journal of General Virology 66 1941-1951.

Park JB \& Kendrick JW 1973 The isolation and partila characterization of a herpesvirus from a case of bovine metritis. Archiv Für Die Gesamte Virusforschung 41 211-215.

Peterson RB \& Goyal SM 1988 Propagation and quantitation of animal herpesviruses in eight cell culture systems. Comparative Immunology Microbiology and Infectious Diseases 11 93-98.

Poyser NL 1987 Effects of various factors on prostaglandin synthesis by the guinea-pig uterus. Journal of Reproduction and Fertility $\mathbf{8 1}$ 269-276.

Poyser NL 1995 The control of prostaglandin production by the endometrium in relation to luteolysis and menstruation. Prostaglandins, Leukotriens, and Essential Fatty Acids 53 147-195.

Reiss CS \& Komatsu T 1998 Does nitric oxide play a critical role in viral infections? Journal of Virology 72 4547-4551.

Reynolds AE \& Enquist LW 2006 Biological interactions between herpesviruses and cyclooxygenase enzymes. Reviews in Medical Virology 16 393-403.

Ruder CA, Sasser RG, Williams RJ, Ely JK, Bull RC \& Butler JE 1981 Uterine infections in the postpartum cow. II. Possible synergistic effect of Fusobacterium necrophorum and Corynebacterium pyogenes. Theriogenology 15 573-580.

van Santen VL 1991 Characterization of the bovine herpesvirus 4 major immediate-early transcript. Journal of Virology 65 5211-5224.

van Santen VL 1993 Characterization of a bovine herpesvirus 4 immediate-early RNA encoding a homolog of the Epstein-Barr virus $\mathrm{R}$ transactivator. Journal of Virology 67 773-784.

Schweizer M \& Peterhans E 2001 Noncytopathic bovine viral diarrhea virus inhibits double-stranded RNA-induced apoptosis and interferon synthesis. Journal of Virology 75 4692-4698.

Sheldon IM \& Dobson H 2004 Postpartum uterine health in cattle. Animal Reproduction Science 82-83 295-306.

Simmen RC, Srinivas V \& Roberts RM 1989 cDNA sequence, gene organization, and progesterone induction of mRNA for uteroferrin, a porcine uterine iron transport protein. DNA 8 543-554.

Smith WL, Garavito RM \& DeWitt DL 1996 Prostaglandin endoperoxide $\mathrm{H}$ synthases (cyclooxygenases)-1 and -2. Journal of Biological Chemistry 271 33157-33160.

Snijdewint FG, Kalinski P, Wierenga EA, Bos JD \& Kapsenberg ML 1993 Prostaglandin E2 differentially modulates cytokine secretion profiles of human Thelper lymphocytes. Journal of Immunology $\mathbf{1 5 0}$ 5321-5329. 
Song MJ, Li X, Brown HJ \& Sun R 2002 Characterization of interactions between, R.T.A., and the promoter of polyadenylated nuclear RNA in Kaposi's sarcoma-associated herpesvirus/human herpesvirus 8. Journal of Virology 76 5000-5013.

Stabel JR \& Stabel TJ 1995 Immortalization and characterization of bovine peritoneal macrophages transfected with SV40 plasmid DNA. Veterinary Immunology and Immunopathology 45 211-220.

Steer SA \& Corbett JA 2003 The role and regulation of COX-2 during viral infection. Viral Immunology 16 447-460.

Storz J, Ehlers B, Todd VJ \& Ludwig H 1984 Bovine cytomegaloviruses: identification and differential properties. Journal of General Virology 65 697-706.

Sun R, Lin SF, Gradoville L, Yuan Y, Zhu F \& Miller G 1998 A viral gene that activates lytic cycle expression of Kaposi's sarcoma-associated herpesvirus. PNAS 95 10866-10871.

Thiry E, Meersschaert C \& Pastoret PP 1988 Epizootiology of herpesvirus infections in wild ruminants. I. Infectious bovine rhinotracheitis virus and antigenically related viruses. Revue D'élevage et De Médecine Vétérinaire Des Pays Tropicaux 41 113-120.

Truman D, Ludwig H \& Storz J 1986 Bovine herpesvirus type 4: studies on the biology and spread in cattle herds and in insemination bulls. Journal of Veteterinary Medicine (Series B) 33 485-501.
Usherwood EJ, Stewart JP \& Nash AA 1996 Characterization of tumor cell lines derived from murine gammaherpesvirus-68-infected mice. Journal of Virology 70 6516-6518.

Vanderplasschen A, Goltz M, Lyaku J, Benarafa C, Buhk HJ, Thiry E \& Pastoret PP 1995 The replication in vitro of the gammaherpesvirus bovine herpesvirus 4 is restricted by its DNA synthesis dependence on the $S$ phase of the cell cycle. Virology 213 328-340.

Wellemans G, Van Opdenbosh E \& Mammerickx M 1986 Inoculation expérimental du virus LVR 140 (herpes bovin IV) à des vaches gestantes et non-gestantes. Annales de Recherches Vétérinaires 17 89-94.

Zimmermann W, Broll H, Ehlers B, Buhk HJ, Rosenthal A \& Goltz M 2001 Genome sequence of bovine herpesvirus 4, a bovine Rhadinovirus, and identification of an origin of DNA replication. Journal of Virology 75 1186-1194.

Received 7 February 2007

First decision 6 March 2007

Revised manuscript received 13 March 2007

Accepted 29 March 2007 